\title{
Chemistry and pharmacology of some plants mentioned in the letter of Pero Vaz de Caminha
}

Lucio F Alves* and Lin C Ming²

Guest editors: Maria F.T. Medeiros and Alain Touwaide

\begin{abstract}
Brazil has a long tradition in the study of medicinal plants. When the Portuguese arrived to the new colony, Pero Vaz de Caminha, the scriber of the fleet, left the first impressions of the local and the inhabitants. He clearly mentions how the Indians use natural dye as tincture to paint their bodies. This article reviews the phytochemical and pharmacological characteristics of these colorants and other medicinal plants recently identified mentioned in this letter.
\end{abstract}

Keywords: Ethnobotany - Historical ethnobiology - Medicinal plants - Natural products

\section{INTRODUCTION}

The first description of Brazilian natural richness is the letter Pero Vaz de Caminha, sent to D. Manoel, king of Portugal, soon after the arrival of Cabral in 1500. The letter is considered Brazil's birth certificate. Talking about the appearance of the original inhabitants, Caminha, the scriber of the expedition, penned: 'They go about naked, without clothing. They do not bother about to cover or to uncover their bodies, and show their private parts as readily as they show their faces. In this matter they are of great innocence. Walking among them there were three or four women, young and gentle, with their hair very black and very long, loose to their backs; their private parts, so prominent and so neat, and so clean of their hairs that we, by very much looking at them, did not get ashamed (...) and sure she was so good shaped and so rounded, and her private part so graceful that most women in our land, if had seen those features would feel abashed for not having their own like she has hers" (Caminha [1500], 2013).

In some parts of his letter Caminha also described the reddish and black color of their bodies. "They are brown skinned, of a quite reddish complexion, with handsome faces and noses, in such "scarved" features. There was one man there, who spoke much to the others, telling them to go away, but they did not, in my opinion, they respected or feared him. This one who was telling them to move carried his bow and arrows, and was painted with red paint on his breasts and shoulder blades and hips, thighs, and legs, all the way down, and the unpainted places such as the stomach and belly were of their own color, and the paint was so red that the water did not wash away or remove it, but rather when he came out of the water he was redder (...). Some of them

1 Fundação Oswaldo Cruz - Setor de Produtos Naturais - Av Sizenando Nabuco 100

* Corresponding author-Email adress: lucioalves@far.fiocruz.br

2 Universidade Estadual Paulista Júlio de Mesquita Filho - Faculdade de Ciências Agronômicas Fazenda Experimental Lageado Botucatu. 
were carrying prickly green nut shells from trees, which in color resembled chestnuts, except that they were very much smaller. And these were full of small red grains which, when crushed between the fingers, made a very red paint with which they were painted. And the wetter they got, the redder they became. They are all shaved above the ears, as well as their eyebrows and eyelashes. All of them have their foreheads from temple to temple painted with a black paint, which looks like a black ribbon the breadth of two fingers" (Caminha [1500] 2013).

The red color came from bixin (1, Figure 1), the pigment from the seeds of urucum, Bixa orellana $\mathrm{L}$. while the black dye, genipin (2, Figure 2), came from Genipa americana L.

As a matter of fact, Caminha never mentioned a plant as being medicinal. The Portuguese stayed here for less than two weeks. All he says is 'rice', 'fruits', 'seeds', 'palms', 'yam'. However, Andradelima (1984) and Filgueiras and Peixoto (2002) suggested that the basket the Indians carried the seed of urucum could be fruits of Lagenaria vulgaris L. These authors also identified, from species levels, some plants mentioned in Caminha's letter: Euterpe americana Mart., Astrocaryum ayri Mart., Attalea funifera Mart., Halodule wrightii Asch., $H$. emarginata Hartog, Gynerium sagitatum (Aubl.) P.Beauv., Bixa orellana L., Protium heptaphyllum (Aubl.) Marchand, Genipa americana L. and Lagenaria siceraria (Molina) Standl. Phytochemical and pharmacological analysis has been made with the last four. The use of urucum and genipin, either in medicine or as body tincture, was mentioned by Gabriel Soares de Sousa, Fernão Cardim, Piso, Langsdrorff, Freire Allemão, Hans Staden and other naturalists or travelers (Alves 2010, 2013).

In this paper, we will discuss the chemistry and pharmacology of these two colorants and other medicinal plants mentioned in the letter of Pero Vaz de Caminha

\section{Bixa orellana L.}

Native to Central and South America, urucum, also known as açafrão, açafroa, annatto, urucu, has been used in traditional medicine for many ailments (Mors et al. 2000; Lorenzi and Matos 2008). It is a bushy shrub with a height ranging from 3 to
10 meters. Bark is more or less smooth with many warty lenticels. Leaves are ovate with a round, heartshaped base and a pointed tip. The flowers are white, pink, or purple colored (Venugopalan et al. 2011). Its use has been traced to the 15th and 16th centuries when tribes of Central and South America employed it extract as body painting to rid them from evil spirits well as an insect repellent (Venugopalan et al. 2011).

Bixin, is an apocarotenoid and the first cispoliene of natural origin. Along with norbixin it is the main component of urucum. Other apocarotenoids, rather than bixin, have been isolated by Jondiko and Pattenden (1989) and Mercadante et al. (1996, 1997, 1999).

A pentacyclic triterpene named tomentosic (3, Figure 1) acid was isolated from its root (Schneider et al. 1965) and a tetracyclic sequiterpene, ishwarane, along with a series essential oils were obtained by Lawrence and Hogg (1973). Galindo-Cuspinera et al. (2002) detected 107 compounds, of several classes (alcohols, aldehydes, alkanes, alkenes, ketones, and terpenes) 51 of which were positively identified. The presence of free fatty acids, alcohols, aldehydes, ketones, sulphur compounds, furans, esters, hydrocarbons, monoterpenes, diterpenes and sesquiterpeness was isolated by Giorgi et al. (2013).

From the fatty soluble antioxidant fraction Frega et al. (1998) reported the isolation of tocotrienols, mainly $\alpha$-tocotrienol. Monzote et al. (2013) identified 73 essential oils from its seeds, of which ishwarane (4, Figure 1) and geranylgeraniol (5, Figure 1) were the major components ( $18.6 \%$ and $9.1 \%$, respectively).

Its roots are used as digestive and diuretic, fresh shoots steeped in water as an eye wash for inflamed eyes, leaf decoction to lessen vomiting during pregnancy. The seed paste is indicated as an aphrodisiac and as protection against insect stings and in syrup against pharyngitis and bronchitis. The seeds are also recommended in cases of intestinal catarrh, measles and as an emmenagogue (Lorenzi and Matos 2008; Mors et al. 2000).

In his História Natural e Médica das Índias Ocidentais, Piso ([1648], 1954) observed that the grains of this plant, when new, ripe and dry, and reduced to tablets are mixture with the pulp Tipioca are useful in envenomation or to any other illness. It is an exaggeration, of course. However, its use as anti-inflammatory, analgesic, as radical scavengers, 
antidiarrheal, anticonvulsant, in the treatment of gastric ulcers, antibacterial against Escherichia coli, Staphylococcus aureus, and Shigella dysenteriae has been recorded (Shilpi et al. 2006).

The ethanolic extract of its seeds and leaves showed activity against Gran positive and Gran negative bacteria like Bacillus subtilis, Streptococcus pyogens, Salmonella typhi, Pseudomonas aeruginosa, and the yeast like fungus Candida albicans (Fleischer et al. 2003; Venugopalan and Giridhar 2012). Stem's, leaves' and root's extracts showed activity against Bacillus cereus, S. aureus, Salmonella tiphinurium, $P$. aeruginosa, Pseudomonas mirabilis and Mycobacterium tuberculosis (Silva et al. 2010). The same extract also showed activity against Bacillus pumilus (Castello et al. 2002). Antimicrobial activity against Kleibsiella pneumoniae, Enterococcus fecalis, Vibrio cholera, Moracella catharrhalis along with fungal pathogens Aspergillus niger and the dermatophytes Trichophyton mentagrophytes and T. rubrum have also been observed (Tamil Selvi et al. 2011). A preliminary data from the volatile components of annatto as insect (Aedes aegypt) repellent was detected by Giorgi et al. (2013) corroborating its use by the Indians.

In an experiment to verify the neutralization of the hemorrhagic effect of the venom of Bothrops atrox, Otero et al $(2000 \mathrm{a}, \mathrm{b}, \mathrm{c})$ tested 75 extracts of plants used in traditional medicine for snake bites. The results demonstrated that 31 extracts $(41.3 \%)$ had in vitro moderate or high neutralizing ability against the hemorrhagic effect of the venom and that Bixa orellana (with other 11 species) was $100 \%$ effective. Later, the same group determined the neutralizing activity of 12 ethanolic extracts against the edemaforming, defribrinating and coagulant effects of $B$. asper venom. According to the authors, all extracts were partially effective in a dose-dependent manner, with $B$. orellana, and three other species, showing the highest effect (Nuñes et al. 2004).

The hypolipidemic property of its seeds (Ferreira et al. 2013), the diuretic activity of its leaves (Radhinka et al. 2010), its anticonvulsant action (Patnaik et al. 2011), its antitumor effect (Matuo et al. 2013; Pierpaoli et al. 2013) and its antigenotoxic, antimutagenic and clastogenic potential (Antunes et al. 2005; Junior et al. 2005) have also been demonstrated.
Annatto also lowers blood glucose in dogs (Russell et al. 2005, 2008) and mice (Patnaik et al. 2011). It also lowers the levels of LDL (low density lipoprotein, the 'bad cholesterol') and total cholesterol, and, at the same time, it raised that of HDL (high density cholesterol, the 'good cholesterol'), then suggesting a hypocholesterolomic effect (Paula et al. 2009).

It has also been demonstrate that Bixa orellana can also surpass the adverse effects of some drugs. For example, isoprenalin (or isoproterenol) is a potent, non-selective adrenergic agonist receptor used in emergencies to stimulate heart rate in patients with bradycardia or heart block. However, its adverse effects may include palpitation, tachycardia, cardiac ischemia and arrhythmias (Goodman and Gilman 1996).

Pretreatment with the ethanolic extract of annatto offered protection against isoproterenolinduced myocardial injury in rats (Asokkumar et al. 2012).

Bixin itself and its derivatives exert protective effects against retinal degeneration induced by tunicamycin both in vivo and vitro, by inhibiting an early apoptotic event and following caspase-3 activation (Tsuruma et al. 2012). Its antioxidant properties are associated with its ability to scavenge free radicals, which, in turn, reduce damage and protect tissues against toxicity caused by antitumoral drugs such as cisplatin (Rios et al. 2009; Santos et al. 2012).

Geranylgeraniol, one of the main component of the oil isolated from its seeds showed activity against the intracellular amastigote form of Leishmania amazonensis (Lopes et al. 2012; Monzote et al. 2013), while ishwarane exhibited moderate antifungal activity against Candida albicans, low activity against Tricophyton metagrophytes, and low antibacterial activity against $E$. coli, $S$. aureus and $P$. aeruginosa, but was inactive against $B$. subtilis and A. niger (Raga et al. 2011).

The anti-inflammatory property of urucum is associated, at least in part, with its antibradykinin activity, reduction of NO production and inhibition of vascular endothelial growth factor (VEGF) (Yong et al. 2011, 2013a,b). As regards to these antibacterial properties mentioned above, annatto can also be used as colorant in food industry. It is safe, without 
mutagenic, carcinogenic or toxic side effect (Agner et al. 2004; Bautista et al. 2004; Alves de Lima et al. 2003; Karchuli and Ganesh 2009; Paumgarten et al. 2002; Viuda-Martos et al. 2012). Annatto is also important in cosmetic industries especially lipstick then its nickname of 'lipstick industries' (Venugopalan et al. 2011).<smiles>COC(=O)/C=C/C(C)=C\C=C\C(C)=C\C=C\C=C(C)\C=C\C=C(C)\C=C\C(=O)O</smiles>

1 - bixin<smiles>CC1(C)CCC2(C(=O)O)CCC3C(=CCC4C3CCC3C(CO)C(O)C(O)CC43C)C2C1O</smiles>

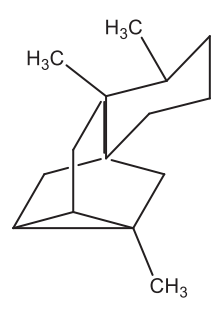

4 - ishwarane

3 - tomentosic acid<smiles>CC(C)=CCC/C=C/CC(O)/C=C(\C)CCC=C(C)C</smiles>

5 - geranylgeraniol

Figure 1. Structures of bixin (1), tomentosic acid (3), ishwarane (4), geranylgeraniol (5).

\section{Genipa americana L.}

The mention of genipin is as older as that of bixin. Gabriel Soares de Sousa, Fernão Cardim ([1585], 1997), Hans Staden ([1557], 1988) and Wilen Piso ([1648], 1954) described, with almost the same words, its use as body tincture. They observed that, when isolated from the fruits, the ink is blank. However, after some after application it acquired a black colour well appreciated by the Indians. Sousa, Cardim and Piso attributed wound healing properties to the fruit of this plant (Alves 2010, 2013). Piso ([1648], 1954) also suggested that this black colour serves to frighten the enemies.

The structure of genipin was established in 1961 by Djerassi et al., almost five centuries after the first descriptions made by earlier naturalists. It is the aglycone of geniposide (Guarnaccia et al. 1972). Genipin and/or geniposide can also be found in Randia spinosa (Hamerski et al. 2003), Eucommia ulmoides (Hirata et al. 2011; Nam et al. 2013; Zhang et al. 2013), Castilleja tenuiflora (Carrilo-Ocampo et al. 2013) and Bellardia trixago (Venditti et al. 2013). Geniposide is hydrolyzed to the aglycone genipin by bacterial enzymes in the intestines and the liver (Jeon et al. 2011).

Their pharmacological and phytochemical properties have been studied by several authors. In 1991, Ueda et al. reported the isolation of iridoid glycosides geniposide (6, Figure 2) and geniposidic acid (7, Figure 2$)$ from the fruits and of 
geniposidic acid from the leaves of jenipapo. On callus induction, the plant produces geniposidic acid and gardenoside (8, Figure 2) in high levels. These iridoids show anti-tumor activities. Some fifteen year later, Ono et al $(2005,2007)$ found four new iridoid glycosides: genameside A-D (9-12, Figure 2) and still later, three new monoterpenoids: genipacetal (13, Figure 2), genipamide (14, Figure 2), and genipaol (15, Figure 2). No therapeutic activity was attributed either to glycosides or to terpenoids. On the other hand, Conceição et al. (2011) isolated only steroids which showed a significant anticancer effect associated to inhibition and reactivation to ERKI/2 and $\mathrm{p} 38$ in Be Wo cells.

Studies of genipin and geniposide isolated from the fruits of Gardenia jasminoides Ellis have shown that either the latter or the former can be useful in the treatment of allergic asthma (Deng et al. 2013), ophthalmic disease (Koriyama et al. 2013; Song et al. 2013), antiviral (Lin et al. 2013), cardiovascular disorders (Hwa et al. 2011; Jiang et al. 2013; Zhang et al. 2013), vitiligo (Jun et al. 2008), angle sprain (Chen et al. 2009), antidepressant (Tian et al. 2010), traumatic brain injury (Hughes et al. 2014), Alzheimer (Gao et al. 2014; Nam and Lee 2013), in diabetes (Guan et al. 2013; Guo et al. 2012; Liu et al. 2012, 2013a,b; Ma et al. 2013; Qiu et al. 2012), in inflammation (Fu et al 2012; Khanal et al. 2014; Li et al. 2012; Wang et al. 2012; Zhang et al. 2012), hepatic ischemia (Kim et al. 2013) and cancer (Ayyasamy et al. 2011; Dando et al. 2013; Khanal et al. 2012; Kim et al. 2012; Wang et al. 2012; Yang et al. 2013).

In many cases, the mechanisms of action underlying genipin and geniposide properties have been established. For example, intraperitoneal treatment with geniposide prevents eosophinolic pulmonary infiltration, attenuates the increases of interleukins IL-4, IL-5 and IL-13, making it an effective adjuvant for the treatment of allergic asthma (Deng et al. 2013).

Genipin suppresses of UCP-2 (uncoupling protein 2), a mitochondrial carrier protein involved in the negative regulation of insulin secretion (Zhang et al. 2006). Over expression of UCP2 is also involved in many types of cancer. It also regulates the activation of proapoptotic proteins and improves insulin sensitivity by promoting insulin-stimulated glucose consumption and glycogen synthesis. In addition, genipin, in a dose and time dependent way increases the expression of peroxisome proliferator-activated receptor, which, in turn, inhibits vascular cell adhesion molecule-1, a protein that mediates the cell adhesion of lymphocytes, monocytes, eosinophils and basophils to vascular endothelium, and may play a role in the development of atherosclerosis. Genipin down-regulates the production of pro-inflammatory cytokines (TNF- $\beta$, IL-1, IL-6), reduces the activation of NF-k $\beta$ (nuclear factor-beta), a protein complex linked to cancer, inflammatory and autoimmune diseases, and inhibits the expression of COX-2, an enzyme involved in the inflammatory process. Moreover, genipin induces the expression and activity of $\mathrm{HO}$ 1 , an inducible isomer of heme oxygenase $(\mathrm{HO})$, a microsomal enzyme that contributes to the antiinflammatory of cells and tissues.

These results make the use of genipin a good candidate against diabetes and cancer. (Ayyasamy et al. 2011; Dando et al. 2013; Guan et al. 2013; Hwa et al. 2011; Jeon et al. 2011; Jiang et al. 2013; Khanal et al. 2012; Kim et al. 2012; 2013; Li et al. 2012; Qiu et al. 2012; Liu et al. 2013; Wang et al. 2012; Wang J et al. 2012; Wang N 2012; Yang et al. 2013).

Geniposide shows similar actions. It blocked the production of TNF- $\alpha$, IL- 6 and IL-1 $\beta$ potentiates the expression of HO-1, increases insulin secretion through-like peptide receptors, prevents or improves the impairment of insulin secretion in $b$ cells challenged with high concentration of glucose, decreases the level of $A b$ 1-42, a major component of amyloid plaques that accumulates in neurons of Alzheimer's disease. Like genipin, geniposide significantly inhibits platelet aggregation induced by thrombin/collagen and venous thrombosis induced by tight ligation of the inferior vena cava (Fu et al. 2012; Guo et al. 2012; Kim et al. 2012; Liu et al. 2012; Liu et al. 2013a,b; Wang J et al. 2012; Wang N 2012; Zhang et al. 2013a,b).

Thus, geniposide may be an efficient drug in the treatment of inflammation, diabetes, Alzheimer's and thrombotic diseases. Geniposide also exerts protective effects against hepatic steatosis, a process which describes the abnormal retention of lipid (Ma et al. 2011). It was also demonstrated that the lethal dose of geniposide was $1431.1 \mathrm{mg} / \mathrm{kg}$ (Ding et al. 2013). 
<smiles>OCC1=CCC2C(Br)=COC(O)C12</smiles><smiles>CC(=O)C1=COC(O)C2C(CO)C=CC12</smiles>

8 - gardenoside, glc $=\beta-$ glycopyranosy<smiles>O=C(O)C1=CO[C@@H](OC2OC(CO)C(O)C(O)C2O)C2C(CO)=CCC12</smiles>

11 - genameside $\mathrm{C}=\mathrm{R}_{1}=\mathrm{R}_{4}=\mathrm{H}, \mathrm{R}_{2}=\mathrm{CH}_{3}, \mathrm{R}_{3}=\mathrm{GlC}$ 12 - genameside $D=R_{1}=G l c, R_{2}=C H_{3}, R_{3}=R_{4}=H$<smiles>CC(=O)CCCN1C=C(C(C)=O)C2CC=C(CO)C2C1=O</smiles>

14 - genipamide
2 - genipin $R=C_{2} M e, R_{1}=H$
6 - geniposide $R=C O_{2} M e, R_{1}=$ glycose
7 - geniposidic acid $R=C O_{2} H, R_{1}=g l c=\beta$

glycopiranosyl

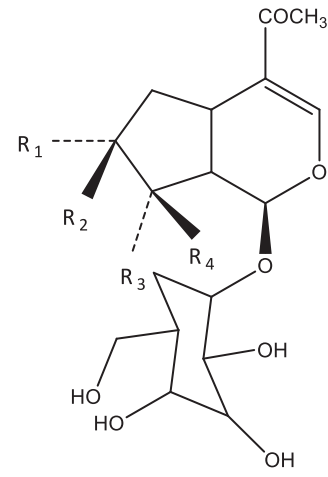

9 - genameside $A=R_{1}=R_{4}=O H, R_{2}=H, R_{3}=C_{3} O H$

10 - genameside $B=R_{1}=H, R_{2}=R_{3}=O H, R_{4}=C_{2} O H$

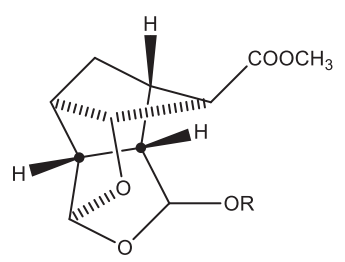

13 - genipacetal<smiles>CC(=O)C1=COC(O)C2(O)C(CO)=CC=C12</smiles>

15 - genipaol

Figure 2. Structures of genipin (2), geniposide (6), geniposidic acid (7), gardenoside (8), genameside A-D (9-12), genipacetal (13), genipamide (14), genipaol (15).

\section{Protium heptaphyllum (Aubl.) Marchand}

P. heptaphyllum, also known as almecega, breu-branco, elemi, icicariba is largely found in North and Northeast Brazil and traditionally used for many ailments (Mors et al. 2000; Lorenzi and Matos 2008). The plant, with its medicinal use, was described by Gabriel Soares de Sousa, Fernão Cardim, Wilen Piso and Luis Gomes Ferreira, naturalists who visited Brazil in the colonial time (Alves 2010, 2013).

Its resin is rich in pentacyclic triterpenes like $\alpha$ - and $\beta$-amyrins (16-17, Figure 3 ) (Susunaga et al. 2001) which are responsible for their therapeutic 
actions, analgesic (Aragão et al. 2007; Chicca et al. 2012; Otuki et al. 2005; Silva et al. 2011), anti-inflammatory (Aragão et al. 2007; Oliveira et al. 2004a; Siani et al. 1999; Silva et al. 2011), periodontitis (Pinto et al. 2008), colitis (Matos et al. 2013; Vitor et al. 2009), pancreatitis (Melo et al. 2010, 2011), hepatoprotective (Oliveira et al. 2005), gastroprotective (Araújo et al. 2011; Oliveira el al. 2004a,b,c;), antihyperglycemic (Santos et al. 2012), antihyperglycemic (Santos et al. 2012), anxiolytic and antidepressant (Aragão et al. 2006) and antipruritic (Oliveira et al. 2004a). Its esters and acetate also possess anticancer (Barros et al. 2011), antimicrobial (Diaz-Ruiz et al. 2012) antihyperglycemic activities (Singh et al. 2009).

The mechanisms of action responsible for its anti-inflammatory and antinociceptive (which are often associated) have been discussed for several authors. Usually, it has been attributed to the increasing COX-2 and EGF expression (Araújo et al. 2011; Silva et al. 2011; Vitor et al. 2009). Its visceral nociception involves the opioid and vaniloid mechanism (Lima-Junior et al. 2005).

The inhibition of protein kinase-A and protein kinase- $C$ was suggested by Otuki et al. (2005) and Chicca et al. (2012), respectively. Another possible mechanism for the activity of amyrins is that of cannabinoid receptors (Chicca et al. 2012; Matos et al. 2013; Silva et al. 2011).

In pancreatitis, they greatly suppressed inflammatory cell infiltration, acinar cell necrosis, the expression of TNF- $\alpha$ and the inducible nitric oxide synthase, decreases the serum levels of amylase and lipase and of interleukin IL-6 and the activity of pancreatic mieloperoxidase (MPO) (Melo et al. 2010, 2011).

Both $\alpha-$ and $\beta$-amyrin attenuates acute periodontal inflammation by reducing neutrophils infiltration, oxidative stress, the production of the pro-inflammatory cytokine TNF- $\alpha$ and the inhibition of gingival MPO (Pinto et al. 2008), while the sedative effect of these two pentacyclic triterpenes involves benzodiapene-type receptors (Aragão et al. 2006) while its antipruritic action may be related to a stabilizing effect on mast cell membrane (Oliveira et al. 2004a).

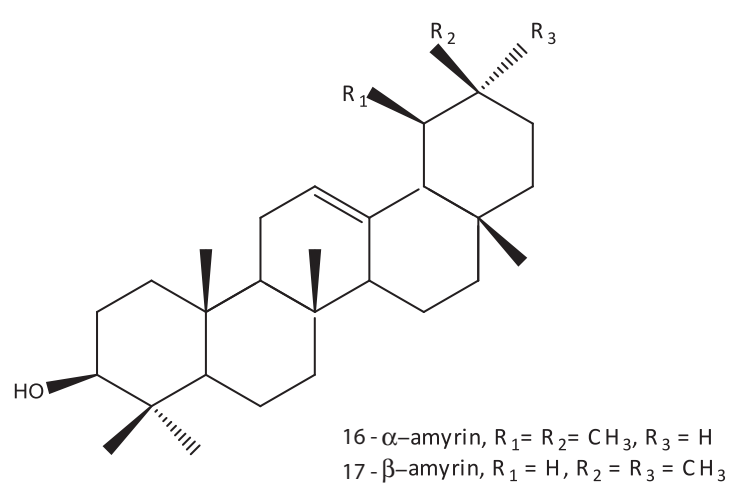

Figure 3. Structures of amyrin (16), amyrin (17).

\section{Lagenaria siceraria (Molina) Standl.}

Known as calabash, opo squash, bottle gourd and long melon in English and as cabaça cuia, cuieté, jamaru, porongo and taquera in Brazil, was one of the first cultivated plant in the world, grown not primarily for food, but for use as a water container. It may have been carried from Africa to Asia, Europe and the Americas in the course of human migration or by seeds floating across the oceans inside the gourd. It has been proven to be in New World prior to the arrival of Columbus. Although indigenous to Africa this species reached America from Asia by 10,000 years before present (B.P.) and had a broad New World distribution by 8,000 B.P. (Erickson et al. 2005).

It contains pentacyclic triterpenes, sterols, flavonoid glycosides and polysaccharides which may be responsible for its therapeutic properties (Chen et al. 2009; Ghosh et al. 2008, 2009).

From the methanolic extracts of its fruits Gangwal et al (2010), isolated oleanolic acid, sitosterol, campesterol, isoquercitrin and kaempferol, while Chen et al. (2008), reported the isolation, identification and structural elucidation of nine (four new and five known) D:C friedooleanane type triterpenes from its stem (18-26, Figure 4). One of the new (20) and one of known (26) showed significant anticancer activity against the SK-Hep 1 cell lines.

Preliminary studies show that its leaves and/ or fruits may be used as analgesic (Shah and Seth 2010), anti-allergic (Jasani et al. 2012), anti-asthmatic 
(Jasani et al. 2012), anticancer (Killedar et al. 2012; Saha et al. 2011; Sen et al. 2013), antidepressant (Prajapati et al. 2011), antihyperlipidemic (Ghule et al. 2006a,b, 2009), antimicrobial (Rodge and Biradar 2012), antioxidant (Deshpande et al. 2007; Erasto et al. 2009; Mayakrishnan et al., 2012, Sharma et al. 2013), cardioprotective (Fard et al. 2008; Saha et al. 2011; Upaganlawar and Balaraman 2011), anti-diabetes (Teugwa et al. 2013), hepatoprotective (Lakshmi et al. 2011), in obsessive compulsive disorder (Prajapati et al. 2011) and in urolithiasis (Takawale et al. 2012).

Phytochemical and pharmacological reviews have been described (Aslam and Najam 2013; Deshpande et al. 2008; Gorasiya et al. 2011; Kubde et al. 2010; Kumar et al. 2012; Tyagi et al. 2012). However, for the most part, the bioactive principles responsible for such activities remain to be elucidated.

Tests with different extracts show different results. The analgesic property of methanolic and aqueous extracts of its fruits was evaluated. The former showed a moderate activity, while the latter showed a significant one (Shah and Seth 2010).

Hyperlidemia, a pathology characterized by an increased level of total cholesterol, triglycerides and low-density protein along with a decrease in highdensity lipoprotein cholesterol, is closely associated with the development of atherosclerosis. Ghule et al. (2006a,b, 2009) tested the hypolipidemic effect of oral administration of four different extracts, aqueous, methanolic, petroleum ether and chloroform, from Lagenaria siceraria fruits in experimental hyperlipidemic induced rats. Both chloroform and alcoholic extracts exhibited more significant effects in lowering total cholesterol, triglycerides, and low density lipoprotein along with increase in HDL as compared with the others, while petroleum ether extracted did not show significant activity. The results show a dose-dependent inhibition of total in the levels of cholesterol, triglycerides and lowdensity lipoprotein and a significant increase in that of high density lipoprotein, giving a scientific basis for the use of bottle gourd in coronary diseases.

Kalsait et al. (2011) reported the isolation of four phytosterols, fucosterol, racemosol, stigmasterol and one stigmasterol derivate with a significant activity in lipid profile. The levels of cholesterol, triglycerides, LDL and VLDL (very low density lipoprotein) were reduced while that of $\mathrm{HDL}$ cholesterol increased. These results corroborate the use of $L$. siceraria in the treatment of hyperlidemia.

Another example of the influence of extracts was provided by Rodge and Biradar (2012). The acetone, methanol and distilled water of extracts of leaves exhibited a significant microbial activity against Escherichia coli, Pseudomonas aeruginosa, Staphylococcus aureus, Bacillus subtilis and Candida albicans. Again, petroleum ether showed the least activity.

Pretreatment with Lagenaria siceraria fruits during 51 days protects the heart of rats against cardiotoxicity produced by isoprenalin (Mali and Bodhankar 2010, Upaganlawar and Balaraman 2011), in a similar way of that discussed above for Bixa orellana. Another example is provided by doxorubicin, an anthracycline antibiotic widely used in the chemotherapy of breast cancer. However, its acute administration induces cardiotoxicity manifested by a significant increase in serum creatine-kinase MB isoenzyme and lactate desidrogenase.It also increase lipid peroxidation and free radical formation. Both hydroalcoholic seed and fruit powder extracts of this plant show protective effect against cardiotoxicity induced by doxorubicin (Fard et al. 2008; Singh et al. 2012).

Evaluation of antitumoral activities of aerial parts and fruits of Lagenaria siceraria have been reported. The active principle, however, remains undetermined (Killedar et al. 2012; Saha et al. 2011; Sen et al. 2013). At the same time, Ghosh et al (2008, 2009) reported the isolation and identification of a polysaccharide from the stem of the plant with cytotoxic property against adenocarcinoma cell line (MCF-7).

Ribosome-inactivating proteins are a class of proteins as a putative role in plant's defense against pathogens. They can also act as antitumor, immunosuppressive, antiviral and anti-HIV. Lagenin, an ribosome-inactivating protein was isolated from the seeds of Lagenaria siceraria by Wang and $\mathrm{Ng}$ (2000), corroborating the antitumoral use of this plant.

Bottle gourd fruit extract also protect against hepatotoxicity induced by carbontetrachloride. This protective action is presumably due to its chemical components which prevents the 
accumulation of free radicals and to detoxification mediated by glutathione (Lakshmi et al. 2011).

Although important to any metabolic process, the excessive generation of free radicals is involved in the development of several ailments, such as diabetes, cancer, arteriosclerosis, cardiovascular diseases, arthritis, among others. Natural antioxidants react with free radicals acting as oxygen scavengers, thus protecting cells form cellular damages induced by oxidative stress (Sharma et al. 2013). The antioxidant and free radical potential of Lagenaria siceraria fruits and seeds has been described by several authors (Deshpande at al. 2007; Erasto and Mbwambo 2009; Mayakhrisnan et al. 2012; Mohan et al. 2012; Sharma et al. 2013; Sulaiman et al. 2013).
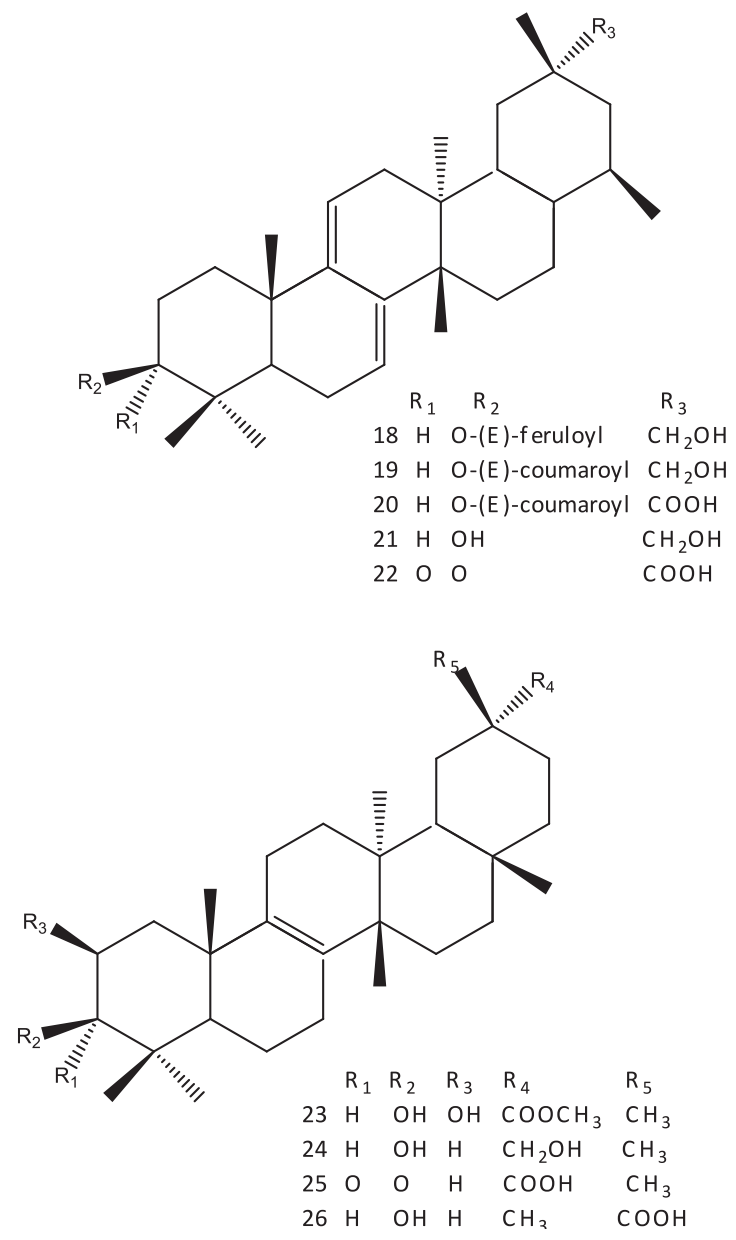

Figure 4. Structures of nine $D: C$ friedooleanane type triterpenes isolated from the stem of Lagenaria siceraria (Molina) Standl.

\section{CONCLUSION}

The letter of Pero Vaz de Caminha, considered as Brazil's birth certificate, describes in few pages the first impression of the new colony. The Portuguese left the new land some days after their arrival. They did not collect any plant for further identification and even less mentioned their medicinal uses.

It was the naturalists who visited Brazil from the $16^{\text {th }}$ to 19 th century who described botanically and therapeutically medicinal plants they found in their journeys to the interior of the country. They left their records in form of books and diaries which still are as a fundamental source of Brazilian natural history (Alves 2010, 2013).

From the letter of Caminha, Bixa orellana and Genipa americana have now been unequivocally identified as the tinctures the Indians painted their bodies. However, the identification of the most of the plants mentioned by Caminha is an open question. According to Andrade Lima (1984) and Filgueiras and Peixoto (2002), the reference to the 'water gourds the Indians carried out is likely to be the fruits of Lagenaria siceraria.

Caminha also described how one man was wearing a sort of wig made of yellow bird feathers, glued to his hair with a material as soft as wax, but which was not wax. This 'wax' seems to be the resin of almecega, Protium heptaphyllum (Andrade-Lima 1974; Filgueiras and Peixoto 2002).

The progress in chemistry and pharmacology showed the potential of their constituents as therapeutic agents.

Despite the structural differences in the main constituents of bixin, genipin and $\alpha-$ and $\beta$-amyrin, they show similar therapeutic activities. The mechanism of action responsible for these properties is well known and was discussed in this article.

It is worth noting that most of the works developed with such plants have been produced in Asia. Special attention should be given by Brazilian scientists to these historical plants. Further studies are needed to evaluate the pharmacological and phytochemical activities of other plants mentioned by Caminha. 


\section{ACKNOWLEDGEMENTS}

LFA is in debt to Dr. Benjamin Gilbert (FarManguinhos) for his kind review and to Dr. Leonardo Lucchetti (Far-Manguinhos) for his helping with drawing the chemical structures.

\section{REFERENCES}

1. Agner AR, Barbisan LF, Scolastici C, Salvadori DMF (2004) Absence of carcinogenic and anticarcinogenic effects of annatto in the rat liver medium-term assay. Food and Chemical Toxicology 42: 1687-1993.

2. Alves de Lima RO, Azevedo L, Ribeiro LR, Salvadori DMF (2003) Study on the mutagenicity and antimutagenicity of natural food colour (annatto) in mouse bone marrow cells. Food and Chemical Toxicology 41: 189-192.

3. Alves LF (2010) Plantas medicinais e fitoquímica no Brasil: Uma visão histórica. Eidtora Pharmabooks, São Paulo, SP, Brasil.

4. Alves LF (2013) Produção de Fitoterápicos no Brasil: História, Problemas, Perspectivas. Revista Virtual de Química 5: 450-513.

5. Andrade-Lima D. (1984) A botânica na carta de Pero Vaz de Caminha. Rodriguesia 36: 5-8.

6. Antunes LMG, Pascoal LM, Bianchi MLP, Dias FL (2005) Evaluation of the clastogenicity and anticlastogenicity of the carotenoid bixin in human lymphocyte cultures. Mutation Research 585: 113-119.

7. Aragão GF, Carneiro LMV, Junior APF, Vieira LC, Bandeira PN, Lemos TLG, Viana GSB (2006) A possible mechanism for ansiolytic and antidepressant effects of alpha- and beta-amyrin from Protium heptaphyllum (Aubl.). March. Pharmacology Biochemostry and Behavior 85: 827-834.

8. Aragão GF, Pinheiro MCC, Bandeira PN, Lemos TLG, Viana GSB (2007) Analgesic and anti-inflammatory activities of the isomeric mixture of alpha- and beta-amyrin from Protium heptaphyllum (Aubl.). March. Journal of Herbal Pharmacotherapy 7:31-47.

9. Araujo DAOV, Takayama C, Faria FM, Socca EAR, Dunder RJ, Manzo LP, Ferreira AL, Souza-Brito ARM (2011) Gastroprotective effects of essential oil from Protium hepatphyllum on experimental gastric ulcer models in rats. Brazilian Journal of Pharmacognosy 21: 721-729.

10. Aslan M, Najam R (2013) A review of pharmacognostical, phytochemical and pharmacological properties of Lagenaria siceraria: A miracle herb. International Journal of Biomedical and Advance Research 4: 266-274.

11. Asokkumar $T$, Jagannath $P$, Umamaheswari $M$, Sivashanmugam T, Subhadradevi V, Madeswaran A. (2012) Cardioprotective activity of Bixa orellana L. on isoproterenol induced myocardial necrosis in rats. Journal of Pharmacy Research 5: 1930-1934.

12. Ayyasamy V, Owens KM, Desouki MM, Liang P, Bakin A, Thangaraj K, Buchsbaum DJ, LoBuglio AF, Singh KK (2011) Cellular model of Warburg effect indentifies tumor promoting function of UCP2 in breast cancer and its suppression by genipin. Plos0ne 6: e24792.

13. Barros FWA, Bandeira PN, Lima DJB, Meira AS, Farias SS, Albuquerque MRJR, Santos HS, Lemos TLG, Morais MO, CostaLotufo LV, Pessoa CO (2011) Amyrin esters induce cell death by apoptosis in HL-60 leukemia cells. Bioorganic \& Medicinal Chemistry 19: 1268-1276.
14. Bautista ARPL, Moreira ELT, Batista MS, Miranda MS, Gomes ICS (2004) Subacute toxicity assessment of annatto in rat. Food and Chemical Toxicology 42: 625-629.

15. Carrillo-Ocampo D, Bazaldúa-Gómez S, Bonilla-Barbosa JR, Aburto-Amar R, Rodrftigues-López V (2013) Anti-inflammatory activity of iridoids and verbascoside from Castilleja tenuiflora. Molecules 18: 12109-12118.

16. Caminha, PA [1500] 2013. Letter from Pero Vaz de Caminha. Available at www.emsbrazil.com/engl/../LetterCaminha.html. [Accessed on November $10^{\text {th }}, 2013$ ].

17. Cardim F [1585] (1997) Tratado da Terra e da Gente do Brasil. Editora Itatiaia, Belo Horizonte, MG, Brazil.

18. Castello MC, Phatak A, Chandra N, Sharon M (2002) Antimicrobial activity of crude extract from plant parts and corresponding calli of Bixa orellana L. Indian Journal of Experimental Biology 40: 1378-1381.

19. Chen CR, Chen HW, Chang C (2008) D:C friedooleanane-type triterpenoids from Lagenaria siceraria and their cytotoxic activity. Chemical and Pharmaceutical Bulletin 56: 385-388.

20. Chen QC, Zhang WY, Youn UJ, Kim HJ, Lee IS, Jung HJ, Na MK, Min BS, Bae KH (2009) Iridoid glycosides from Gardeniae Fructus for the treatment of ankle sprain. Phytochemistry 70: 779-784.

21. Chicca A, Marazzi J, Gertsch J (2012) The antinociceptive triterpene $\alpha$-amyrin inhibits 2-arachidonoylglycerol (2-AG) hydrolysis without directly targeting cannabinoid receptors. British Journal of Pharmacology 167: 1596-1608.

22. Conceição AO, Rosi MH, Oliveira FF, Takser L, Lafond J (2011) Genipa americana (Rubiaceae) fruit extract affects mitogenactivated protein kinase cell pathway in human trofoblastderived BeWo cells: Implication for placental development. Journal of Medicinal Food 14: 483-494.

23. Dando I, Fiorini C, Pozza ED, Padroni C, Costanzo C, Palmieri M, Donadelli M (2013) UCP2 inhibition triggers ROS-dependent nuclear translocation of GAPDH and autophagic cell death in pancreatic adenocarcinoma cells. Biochimica et Biophysica Acta 1833: 672-679.

24. Deng Y, Guan M, Xie X, Yang X, Xiang H, Li H, Zou L, Wei J, Wang D, Deng $X$ (2013) Geniposide inhibits airway inflammation and hyperresponsiveness in a mouse model of asthma. International Immunopharmacology 17: 561-567.

25. Deshpande JR, Mishra MR, Meghre VS, Wadodkar SG, Dorle AK (2007) Free radical scavenging activity of Lagenaria siceraria (Mol.) Standl. fruit. Natural Products Radiance 6: 127-130.

26. Deshpande JR, Choudhari AA, Mishra MR, Meghre VS, Wadodkar, SG, Dorle AK (2008) Beneficial effects of Lagenaria siceraria (Mol.) Standley fruit epicarp in animal models. Indian Journal of Experimental Biology 46: 234-242.

27. Diaz-Ruiz GD, Hérnandez-Vázquez L, Luna $H$, Wacher-Rodarte MC, Navarro-Ocaña A (2012) Growth inhibition of Strptococcus from the oral cavity by $\alpha$-amyrin esters. Molecules 17: 1260312611.

28. Ding Y, Zhang T, Tao JS, Zhang LY, Shi JR, Ji G (2013) Potential hepatotoxicity of geniposide, the major iridoid glycoside in dried ripe fruits of Gardenia jasminoides (Zhi-zhi). Natural Products Report 27: 929-933.

29. Djerassi C, Nakano T, James NA, Zalkow LH, Eisenbruam EJ, Shoolery JN (1961) Terpenoids XLVII. The structure of genipin. Journal of Organic Chemistry 26: 1192-1206. 
30. Erasto P, Mbwambo ZH (2009) Antioxidant activity and HPTLC profile of Lagenaria siceraria fruits. Tanzanian Journal of Health Research 11: 79-83.

31. Erickson DL, Smith BD, Clarke AC, Sandweiss DH, Tuross N (2005) An Asian origin for a $\mathbf{1 0 . 0 0 0 - y e a r - o l d ~ d o m e s t i c a t e d ~ p l a n t ~ i n ~ t h e ~}$ Americas. Proceedings of the National Academy of Sciences 102: 18315-18320.

32. Fard MH, Bodhankar SL, Dikshit M (2008) Cardioprotective activity of fruit of Lagenaria siceraria (Molina) Standley on doxorubicin induced cardiotoxicity in rats. International Journal of Pharmacology 4: 466-471.

33. Ferreira JM, Sousa DF, Dantas MB, Fonseca SGC, Menezes DM, Martins AMC, Queiros MGR (2013) Effects of Bixa orellana L. on hyperlipidemia. Phytotherapy Research 27: 144-147.

34. Filgueiras TS, Peixoto AL (2002) Flora e vegetação do Brasil na carta de Pero Vaz de Caminha. Acta Botanica Brasilica 16: 263272.

35. Fleischer TC, Ameade EPK, Mensah ML, Sawer, IK (2003) Antimicrobial activity of the leaves and seeds of Bixa orellana. Fitoterapia 74: 136-138.

36. Frega N, Mozzon M, Bocci EF (1998) Identification and estimation of tocotrienols in the annatto lipid fraction by gaschromatography-mass spectrometry. Journal of the American Oil Chemical Society 75: 1723-1727.

37. Fu Y, Liu B, Liu J, Liu Z, Li D, Li F, Cao Y, Zhang X, Zhang N, Yang Z (2012) Geniposide, from Gardenia jasminoides Ellis, inhibits the inflammatory response in the primary mouse macrophages and mouse models. International Immunopharmacology 14: 792-798.

38. Galindo-Cuspinera V, Lubran MB, Rankin SA (2002) Comparison of volatile compounds in water- and oil-soluble annatto (Bixa orellana) extracts. Journal of Agricultural and Food Chemistry 50: 2010-2015.

39. Gangwal A, Parmar SK, Sheth NR (2010) Triterpenoids, flavonoids and sterols from Lagenaria siceraria fruits. Der Pharmacia Lettre 2: 307-317.

40. Gao C, Liu Y, Jiang Y, Ding J, Li L (2014) Geniposide ameliorates learning memory deficits, reduces Tau phosphorylation and decreases apoptosis via GSK3b pathway in streptozotocininduced Alzheimer rat model. Brain Pathology 24: 261-269.

41. Ghosh K, Chandra K, Ojha K, Sarkar S, Islam SS (2009) Structural identification and cytotoxic of a polysaccharide from the fruits of Lagenaria siceria (Lau). Carbohydrate Research 344: 693-698.

42. Ghosh K, Chandra K, Roy, SK, Mondal S, Maiti D, Das D, Ojha K, Islam SS (2008) Structural studies of a methyl galacturonosylmethoxyxylan isolated from the stem of Lagenaria siceria (Lau). Carbohydrate Research 343: 341-349.

43. Ghule BV, Ghante MH, Saoji AN, Yeole PG (2006a) Hypolidemic and antihyperlidemic effects of Lagenaria siceraria (Mol.) fruits extracts. Indian Journal of Experimental Biology 44: 905-909.

44. Ghule BV, Ghante MH, Saoji AN, Yeole PG (2006b) Hypolidemic and antihyperlidemic effects of Lagenaria siceraria (Mol.) fruits extracts. Indian Journal of Experimental Biology 44: 905-909.

45. Ghule BV, Ghante MH, Saoji AN, Yeole PG (2009) Antihyperlipidemic effect of the methanolic extract from Lagenaria siceraria Stand. fruit in hyperlipidemic rats. Journal of Ethnopharmcology 124: 333-337.

46. Giorgi A, De Marinis P, Granelli G, Chiesa LM, Panseri S (2013) Secondary metabolites profile, antioxidant capacity, and mosquito repellent activity of Bixa orellana from Brazilian Amazon region. Journal of Chemistry article ID 409826.
47. Goodman, JGH, Gilman, LEL (1996) The Pharmacological Basis of Therapeutics. McGraw Hill. New York, USA.

48. Gorasiya HJ, Paranjape A, Murti K (2011) Pharmacognostic and pharmacological profile of Lagenaria siceraria (Molina) Standely: A review. Pharmacology on line 3: 317-324.

49. Guan L, Feng H, Gong D, Zhao X, Cai L, Wu Q, Yuan B, Yang M, Zhao J, Zou $Y$ (2013) Genipin ameliorates age-related resistance through inhibiting hepatic oxidative stress and mitochondrial dysfunction. Experimental Gerontology 48: 1387-1394.

50. Guarnaccia R, Madyastha KM, Tegtmeyer E, Coscia CJ (1972) Geniposidic acid, an iridoid from Genipa americana. Tetrahedron Letters 50: 5125-5127.

51. Guo, LX, Xia ZN, Gao, X, Yin F, Liu JH (2012) Glucagon-like peptide 1 receptor plays a critical role in geniposide-regulated insulin secretion in INS-1 cells. Acta Pharmacologica Sinica 33: 237-241.

52. Hamerski L, Furlan M, Silva DHS, Cavalheiro AJ, Eberlin MN, Tomazela DM, Bolzani VS (2003) Iridoid glucosides from Randia spinosa (Rubiaceae). Phytochemistry 63: 397-400.

53. Hirata T, Kobayashi T, Wada A, Ueda T, Fujikawa H, Miyashita H, Ikeda T, Tsukamoto S, Nohara T (2011) Anti-obesity compounds in green leaves of Eucommia ulmoides. Bioorganic \& Medicinal Chemistry Letters 21: 1786-1791.

54. Hughes RH, Silva VA, Ahmed I, Shreiber DI, Morrison B (2014) Neuroprotection by genipin against reactive oxygen and reactive nitrogen species-mediated injury in organotypic hippocampal slice culture. Brain Research1543: 308-314.

55. Hwa JS, Mun L, Kim HJ, Seo HG, Lee JH, Kwak JH, Lee DU, Chang KC (2011) Genipin selectively inhibits TNF- $\alpha$-activated VCAM-1 but not ICAM-1 expression by upregulation of PPAR- $\gamma$ in human endothelial cells. Korean Journal of Physiology and Pharmacology 15: 157-162.

56. Jasani N, Kapoor M, Tripathi N, Acharya N, Acharya S, Kumar V (2012) Anti-asthmatic \& anti-allergic activity of Lagenaria siceraria Mol Standley. Journal of Natural Remedies 12: 72-76.

57. Jeon WK, Hong HY, Kim RC (2011) Genipin up-regulates heme oxygenase-1 via PI3-kinase'JNK1/2-Nrf2 signaling pathway to enhance the anti-inflamnmatory capacity in RAW264.7 macrophages. Archives of Biochemistry and Biophysics 512: 119125.

58. Jiang F, Jiang R, Zhu X, Zhang X, Zhan Z (2013) Genipin inhibits TNF- $\alpha$-induced vascular smooth muscle cell proliferation and migration via induction of H0-1. PlosOne 8: e74826.

59. Jondiko IJ, Pattenden G (1989) Terpenoids and an apocarotenoid from seeds of Bixa orellana. Phytochemistry 28: 3159-3162.

60. Jun LW, Yan WH, Wei L, Yu WK, Ming WR (2008) Evidence that geniposide abrogates norepinephrine-induced hypopigmentation by the activation of GLP-1R-dependent c-kit receptor signaling in melanocyte. Journal of Ethnopharmacology 118: 154-158.

61. Júnior ACTS, Asad LMBO, Oliveira EB, Kovary K, Asad NR, Fetzenwalb I (2005) Antigenotoxic and antimutagenic potential of an annatto pigment (norbixin) against oxidative stress. Genetics and Molecular Reserach 4: 94-99.

62. Kalsait RP, Khedekar PB, Saoji AN, Bhusari K (2011) Isolation of phytosterols and antihyperlipidemic activity of Lagenaria siceraria. Archives of Pharmacal Research 34: 1599-1604.

63. Karchuli MS, Ganesh N (2009) Protective effect of Bixa orellana L. against radiation induced chromosomal aberration in Swiss albino mice. International Journal of Phytomedicine 1: 18-21. 
64. Khanal T, Kim HG, Do MT, Choi JH, Chung YC, Kim HS, Park YJ, Jeong TC, Jeng HG (2014) Genipin induces cyclooxygenase-2 expression via NADPH oxidase, MAPKs, AP-1, and NF-kB in Raw 264.7 cells. Food and Chemical Toxicology 64: 126-134.

65. Khanal T, Kim HG, Choi JH, Do MT, Kong MJ, Kang MJ, Noh K, Yeo HK, Ahn YT, Kang W, Kim DH, Jeong TC, Jeong HG (2012) Biotransformation of geniposide by human intestinal microflora on cytotoxicity against HepG2 cells. Toxicology Letters 209: 246254.

66. Killedar SG, Mahamuni SS, More HN, Gadakari SS, Nate AB, Pawar AA (2012) Phytochemical investigation and cytotoxic screening of Lagenaria siceraria Standley. fruit using brine shrimp lethality assay models. International Journal of Pharmaceutical Chemical and Biological Sciences 2: 422-426.

67. Kim ES, Jeong CS, Moon A (2012) Genipin, a constituent of Gardenia jasmioides Ellis, induces apoptosis and inhibits invasion in MDA-MB-231 breast cancer cells. Oncology Reports 27: 567-572.

68. Kim J, Kim HY, Lee SM (2013) Protective effects of geniposide and genipin against hepatic ischemia/reperfusion injury in mice. Biomolecules \& Therapeutics 21: 132-137.

69. Kim TH, Yoon SJ, Lee SM (2012) Genipin attenuates sepsis by inhibiting Toll-like receptor signaling. Molecular Medicine18: $455-465$.

70. Koriyama, Y, Takagi Y, Chiba K, Yamazaki M, Sugitani K, Arai K, Suzuki H, Kato S (2013) Requirement of retinoic acid receptor b for genipin derivative-induced optic nerve regeneration in adult rat retina. Pos0ne 8: e71252.

71. Kubde MS, Khadabadi SS, Faroqui IA, Deore SL (2010) Lagenaria siceraria: Phytochemistry, pharmacognosy and pharmacological studies. Report and Opinion 2:91-98.

72. Kumar A, Partap S, Sharma NK, Jha KK (2012) Phytochemical, ethnobotanical and pharmacological profile of Lagenaria siceraria: A review. Journal of Pharmacognosy and Phytochememistry 1:24-31.

73. Lakshmi BVS, Kumar PUK, Neelima N, Umarani V, Sudhakar M (2011) Hepatoprotective activity of Lagenaria siceraria fruit extracts against carbontetrachloride-induced hepatic damage in rats. Research Journal of Pharmaceutical, Biological and Chemical Sciences 2: 130-137.

74. Lawrence BM, Hogg, JW 1973 Ishwarane in Bixa orellana leaf oil. Phytochemistry 12: 2995.

75. Li CC, Hsiang CY, Lo HY, Pai FT, Wu SL, Ho TY (2012) Genipin inhibits lipopolysaccharide-induced acute systemic inflammation in mice as evidenced by nuclear factor-kB bioluminescent imaging guided transcriptomic analyisis. Food and Chemical Toxicology 50: 2978-2986.

76. Lima-Junior RCP, Oliveira FA, Gurgel LA, Cavalcante. IJM, Santos, KA, Campos, DA, Vale, CAL, Silva, RA, Chaves, MH, Rao, VSN, Santos, FA (2005) Attenuation of visceral nociception of $\alpha$ - and 囚-amyrin, a titerpenoid mixture isolated from the resin of Protium heptaphyllum in mice. Planta Medica 72: 34-39.

77. Lin $\mathrm{YJ}$, Lai CC, Lai $\mathrm{CH}$, Sue $\mathrm{SC}$, Lin CW, Hung $\mathrm{CH}$, Lin $\mathrm{TH}$, Hsu WY, Huang SM, Hung YL, Tien N, Liu X, Chen CL, Tsai FJ (2013) Inhibition of enterovirus 71 infections and viral IRES activity by Fructus gardenia and genipoiside. European Journal of Medicinal Chemistry 62: 206-213.

78. Liu J, Yin F, Xiao H, Guo L, Gao X (2012) Glucagon-like peptide 1 receptor plays an essential role in geniposide attenuating lipotoxicity-induced $\beta$--cell apoptosis. Toxicology in Vitro 26 : 1093-1097.
79. Liu J, Guo L, Yin F, Zhang Y, Liu Z, Wang, Y (2013a) Geniposide regulates glucose-stimulated insulin secretion possibly through controlling glucose metabolism in INS-1 cells. PlosOne 8: e78315.

80. Liu J, Zhang Y, Deng X, Yin F (2013b) Geniposide decreases the level of $A b_{1-42}$ in the hippocampus of sreptozotocin-induced diabetic rats. Acta Biochimica and Biophysica Sinica 45: 787-791.

81. Lopes MV, Desoti VC, Caleare AO, Ueda-Nakamura T, Silva SO, Nakamura CV (2012) Mitochondrial superoxide anion production contributes to geranylgeraniol-induced death in Leishmania amazonenses Evidence Based in Alternative and Complementary Medicine Article ID 298320.

82. Lorenzi H, Matos, FJA (2008) Plantas medicinais no Brasil. Editora Plantarum, Nova Odessa, SP, Brasil.

83. Ma TT, Huang C, Zong GJ, Zha DJ, Meng XM, Li J, Tang WJ (2011) Hepatoprotective effects of geniposide in a rat model of nonalcoholic steatohepatitis. Journal of Pharmacy and Pharmacology 63: 587-593.

84. Ma CJ, Nie AF, Zhang ZJ, Zhang ZG, Du L, Li XY, Ning G (2013) Genipin stimulates glucose transport in $\mathrm{C}_{2}-\mathrm{C}_{12}$ myotubes via an IRS-1 and calcium dependent mechanism. Journal of Endocrinology 216: 353-362.

85. Mali, VR, Bodhankar SL (2010) Cardioprotective effect of Lagenaria siuceraria (LS) fruit powder in isoprenalin-inbduced cardiotoxicity in rats. European Journal of Integrative Medicine 2: $143-149$.

86. Matos I, Bento AF, Marcon R, Claudino RF, Calixto JB (2013) Preventive and therapeutic oral administration of the pentacyclic triterpene $\alpha$-and $\beta$-amyrin ameliorates dextran sulfate sodiuminduced colitis in mice: The relevance of cannabinoid system. Molecular Immunology 54: 482-492.

87. Matuo MC, Takamoto RTO, Kikuchi IS, Pinto JAP (2013) Effect of bixin and norbxin on the expression of cytochrome P450 in HepG2 cell line. Cell Biology International 37: 843-848.

88. Mayakrishman V, Veluswamy S, Sundaram KS, Kannappan $\mathrm{P}$, Abdullah, N (2012) Free radical scavenging potential of Lagenaria siceraria (Molina) Standl fruit extract. Asian Pacific Journal of Tropical Medicine 20-26.

89. Melo CM, Carvalho KMMB, Neves JCS, Morais TC, Rao VS, Santos FA, Brito GAC, Chaves MH (2010) $\alpha$-amyrin, a natural triterpenoid ameliorates L-arginine-induced acute pancreatitis in rats. World Journal of Gastroenterology 16: 4272-4280.

90. Melo CM, Morais TC, Tomé AR, Brito GA, Chaves MH, Rao VS, Santos FA (2011) Anti-inflammatory effects of $\alpha$-amyrin, a triterpene from Protium hepetaphyllum, on cerulein-induced acute pancreatitis in mice. Inflammation Research 60: 673-681.

91. Mercadante $A Z$, Steck $A$, Rodriguez-Amaya $S$, Pfander $H$, Britton G (1996) Isolation of methyl 9'Z-apo-6'-lycopenoate from Bixa orellana. Phytochemistry 41: 1201-1203.

92. Mercadante AZ, Steck A, Pfander $H$ (1997) Isolation and identification of new apocarotenoids from annatto (Bixa orellana) seeds. Journal of Agricultural and Food Chemistry 45: 1050-1054.

93. Mercadante AZ, Steck A, Pfander H (1999) Three minor carotenoids from annatto (Bixa orellana) seeds. Phytochemistry 52: $135-139$.

94. Mohan R, Birari R, Karmase A, Jagtap S, Bhutani KK (2012) Antioxidant activity a new phenolic glycoside from Lagenaria siceraria Stand. fruits. Food Chemistry 132: 244-251. 
95. Monzote L, Garcia M, Scull R, Cuellar A, Setzer, WN (2014) Antileishmanial activity of the essential oils from Bixa orellana. Phytotherapy Research 28: 753-758.

96. Mors W, Rizzini CT, Pereira NA (2000) Medicinal Plants of Brazil. Michigan:Reference Publication. USA.

97. Nam JW, Kim SY, Yoon T, Lee YJ, Kil YS, Lee YS, Seo EK (2013) Heat shock factor 1 inducers from the bark of Eucommia ulmoides as cytoprotective agents. Chemistry and Biodiversity 10: 1322-1327.

98. Nam Y, Lee D (2013) Ameliorating effect of zhizhi (Fructus gardenia) extract and its glycosides on scopolamine-induced memory impairment. Journal of Traditional Chinese Medicine 33: 223-227.

99. Nuñez V, Oliveira R, Barona J, Sadarriaga M, Osorio RG, Fonnegra R, Jimenez SL, Diaz A, Quintana JC (2004) Neutralization of the edema-forming, defribinating and coagulant effects of Bothrops asper venom by extracts of plants used by healers in Colombia. Brazilian Journal of Medical and Biological Research 37: 969-977.

100. Oliveira FA, Lima-Junior RCP, Cordeiro WM, Vieira-Junior GM, Chaves MH, Almeida FRC, Silva RM, Santos FA, Rao VS 2004a Pentacyclic titerpenoids, $\alpha, \beta$ amyrins, suppress the scratching behavior in a mouse model pruritus. Pharmacology Biochemistry and Behavior 78: 719-725.

101. Oliveira FA, Vieira-Junior GM, Chaves MH, Almeida FRC, Florêncio MG, Lima Jr. RCP, Silva RM, Santos FA, Rao, VSN (2004b) Gastroprotective and anti-inflammatory effects of resin from Protium heptaphyllum in mice and rats. Pharmacological Research 49: 105-111.

102. Oliveira FA, Vieira-Junior VM, Chaves MH, Almeida FRC, Santos KA, Martins FS, Silva RM, Santos FA, Rao VSN (2004c) Gastroprotective effect of the mixture of $\alpha$-and $\beta$--amyrin from Protium heptaphyllum: Role of capsaicin-sensitivity primary afferent neurons. Planta Medica 70: 780-782.

103. Oliveira FA, Chaves MH, Almeida FRC, Lima-Junior RCP, Silva RM, Maia, JL, Brito GAAC, Santos FA, Rao VS (2005) Protective effect of $\alpha$ - and $\beta$-amyrin, a triterpene mixture from Protium heptaphyllum (Aubl.) March trunk wood resin, against acetaminophen-induced liver injury in mice. Journal of Ethnophgarmacology 98: 103-108.

104. Ono M, Ueno M, Masuoka C, Ikeda T, Nohara, T (2005) Iridoid glucosides from the fruit of Genipa americana. Chemical and Pharmaceutical Bulletin 53: 1342-1344.

105. Ono M, Ishimatsu N, Masuoka C, Yoshimitsu H, Tsuchihashi $\mathrm{R}$, Okawa M, Kinjo J, Ikeda T, Nohara T (2007) Three new monoterpenoids from the fruit of Genipa americana. Chemical and Pharmaceutical Bulletin 55: 632-634.

106. Otero R, Fonnegra R, Jiménez SL, Núñez V. Evans N, Alzate SP, Garcia ME, Saldarriaga M, Del Valle G, Osorio RG, Diaz A, Valderrama R, Duque A, Vélez HN (2000a) Snakebites and ethnobotany in the northwest region of Colombia. Part I: Traditional use of plants. Journal of Ethnopharmacology 71: 493504.

107. Otero R, Núñez V. Jiménez SL, Fonnegra R, Osorio RG, Garcia ME, Diaz A (2000b) Snakebites and ethnobotany in the northwest region of Colombia. Part II: Neutralization of lethal and enzymatic effects of Bothrops atrox venom. Journal of Ethnopharmacology 71: $505-511$

108. Otero R, Nuñez V, Barona J, Fonnegra R, Jiménez SL, Osório $R G$, Saldarriaga M, Diaz A (2000c) Snakebites and ethnobotany in the northwest region of Colombia. Part III. Neutralization of the hemorrhagic effect of Bothrops atrox venom. Journal of Ethnopharmacology 73: 233-241.
109. Otuki MF, Ferreira J, Lima FV, Meyre-Silva C, Malheiros A, Muller LA, Cani GS, Santos ARS, Yunes RA, Calixto JB (2005) Antinociceptive properties of mixture of $\alpha$-amyrin and $\beta$-amyrin triterpenes: Evidence for participation of protein kinase $C$ and protein kinase A pathways. Journal of Pharmacology and Experimental Therapeutics 313 310-318.

110. Patnaik S, Mishra SR, Choudhury GB, Panda SK, Behera M (2011) Phytochemical investigation and simultaneously study on anticonvulsant, antidiabetic activity of different leafy extracts of Bixa orellana Linn. International Journal of Pharmaceutical \& Biological Archives 2: 1497-1501.

111. Paula H, Pedrosa ML, Rossoni Junior JV, Haraguchi FK, Santos RC, Silva ME (2009) Effect of an aqueous extratct of annatto (Bixa orellana) seeds on lipid profille and biochemicalk markers of renal and hepatic function in hypercholesterolemic rats. Brazilian Archives of Biology and Technology 52: 1373-1376.

112. Paumgarten FJR, Carvalho RR, Araújo IB, Pinto FM, Borges 00, Sousa CAM, Kuriyama, SN (2002) Evaluation of the developmental toxicity of annatto in the rat. Food and Chemical Toxicology 40: 1595-1601.

113. Pierpaoli E, Viola V, Barucca A, Orlando F, Galli F, Provinciali M (2013) Effect of annatto-tocotrienols supplementation on the development of mammary tumors in HER-2/neu transgenic mice. Carcinogenesis 34: 1352-1360.

114. Pinto SAH, Pinto LMS, Cunha GMA, Chaves MH, Santos FA, Rao VS (2008) Anti-inflammatory effect of $\alpha, \beta$-amyrin, a pentacyclic triterpene from Protium heptaphyllum in rat model of acute periodontitis. Inflammapharmacology 16 48-52.

115. Piso, G [1648] (1954) História Natural e Médica das Índias Ocidentais. Companhia Editora Nacional, Rio de Janero, RJ, Brasil

116. Prajapati R, Umbarkar, R, Parmar S, Sheth N (2011) Antidepressant like activity of Lagenaria siceraria (Molina) Standley fruits by evaluation of the forced swim behavior in rats. International Journal of Nutrition, Pharmacology, Neurological Diseases 1: 152-156.

117. Prajapati RP, Kalaria MV, Karkare VP, Pamar SK, Sheth NR (2011) Effect of methanolic extract of Lagenaria siceraria (Molina) Standley fruits on marble-burying behavior in mice: Implicatiuon for obsessive-compulsive disorder. Pharmacognosy Research 3 : 62-66.

118. Qiu W, Zhou, Y, Jiang L, Fang L, Chen L, Su W, Tan R, Zhang CY, Han X, Yang J (2012) Genipin inhibits mitochondrial uncoupling protein 2 expression and ameliorates podocyte injury in diabetic mice. PlosOne 7: e41391.

119. Radhika B, Begun N, Srisailam K, Reddy VM Diuretic activity of Bixa orellana Linn. leaf extracts. (2010) Indian Journal of Natural Products Research 1: 353-355.

120. Raga DD, Espiritu RA, Shen CC, Ragasa CY (2011) A bioactive sesquiterpene from Bixa orellana. Journal of Natural Medicine 65: 206-211.

121. Rios AO, Antunes LMG, Bianchi MLP (2009) Bixin and lycopene modulation of free radical generation induced by cisplatin-DNA interaction. Food Chemistry 113: 1113-1118.

122. Rodge SV, Biradar SD (2012) Preliminary phytochemical screening and antimicrobial activity of Lagenaria siceraria (Mol) Standal. Indian Journal of Plant Science 2: 126-130.

123. Russell KRM, Morrison EY, Ragoobirsingh D (2005) The effect of annatto on insulin binding properties in the dog. Phytotherapy Research19: 433-436. 
124. Russell KR, Omoruyi FO, Pascoe KO, Morrison EY (2008) Hypoglicemic activity of Bixa orellana extract in the dog. Methods and Finds in Experimental and Clinical Pharmacology 30: $301-305$

125. Saha P, Sen SK, Bala A, Mazumder UK, Haldar PK (2011) Evaluation of anticancer activity of Lagenaria siceraria aerial parts. International Journal of Cancer Research 7: 244-253.

126. Santos FA, Frota JT, Arruda BR, Melo TS, Silva AACA, Brito GAC, Chaves MH, Rao VS (2012) Antihyperglycemic and hipolidemic effects of $\alpha, \beta$-amyrin, a triterpenoid mixture from Protium heptaphyllum in mice. Lipids in Health and Disease 11: 98-105.

127. Santos GC, Mendonça LM, Antonucci GA, Santos AC, Antunes LMG, Bianchi MLP (2012) Protective effect of bixin on cisplatininduced genotoxicity in PC12 cells. Food and Chemical Toxcicology 50: 335-340.

128. Schneider WP, Caron EL, Hinman JW (1965) Occurrence of tomentosic acid in extracts of Bixa orellana. Journal of Organic Chemistry 30: 2856-2857.

129. Sen CK, Paul B, Biswas BK, Shahid-Ud-Daula AFM (2013) Cytotoxic effect of Lagenraia siceraria crude extracts obtained from its flowers. International Journal of Phytotherapy Research 3: 15-21.

130. Shah BN, Seth AK (2010) Screening of Lagenaria siceraria fruits for their analgesic activity. Romanian Journal of Biology. Plant Biology 55: 23-26.

131. Sharma NK, Yadav P, Singh HK, Shrivastava K (2013) In vitro antioxidant activity of Lagenaria siceraria leaves. Malaysian Journal of Pharmaceutical Sciences 11: 1-11.

132. Shilpi, JA, Rahman, TU, Uddin, SJ, Alam, S, Sadhu, SK, Seidel, V (2006) Preliminary pharmacological screening of Bixa orellana L. leaves. Journal of Ethnopharmacology 108: 264-271.

133. Siani AC, Ramos MF, Meneses-de-Lima 0, Ribeiro-dos-Santos $R$, Fernades-Ferreira E, Soares ROA, Rosas EC, Susunaga GS, Guimaraes AC, Zoghbi MGB, Henriques MG (1999) Evaluation of anti-inflammatory-related activity of essential oils from the leaves and resin species of Protium. Journal of Ethnopharmacology 66 57-69.

134. Silva RB, Almeida CR, Chavasco JM, Chavasco JK (2010) Antimycobacterial activity evaluation and MIC determination of liophilizated hydroalcoholic extracts of Bixa orelana $\mathrm{L}$. Bixaceae. Brazilian Journal of Pharmacognosy 20: 171-174.

135. Silva, KAS, Paszcuk AF, Passos GF, Silva ES, Bento AF, Meotti FC, Calixto JB (2011) Activation of cannabinoid receptors by the pentacyclic triterpene $\alpha$-amyrin inhibits inflammatory and neuropathic persistent pain in mice. Pain 152: 1872-1887.

136. Singh AB, Yadav DK, Maurya R, Srivastava AK (2009) Antihyperglycaemic activity of alpha-amyrin acetate in rats and db/db mice. Natural Product Research 23: 876-882

137. Singh MK, Mohd F, Ayaz A, Ankur S, Jyoti Y (2012) Protective effect of Lagenaria siceraria against doxorubicin induced cardiotoxicity in wistar rats. International Journal of Drug and Development Research 4: 298-305.

138. Song J, Bi H, Xie X, Guo J, Wang X, Liu D (2013) Natural borneol enhances geniposide ophthalmic absorption in rabbits. International Journal of Pharmaceutics 445: 163-170.

139. Sousa, GS [1825] (2000) Tratado Descritivo do Brasil. Fundação Joaquim Nabuco, PE, Recife. Brasil.

140. Staden, H [1557] (1988) Viagem Ao Brasil. Belo Horizonte Editora Itatiaia, Belo Horizonte, MG, Brasil
141. Sulaiman SF, Ooi KL, Supriatno (2013) Antioxidant and $\alpha$-glucosidase inhibitory activities of cucurbit fruit vegetables and identification of active and major constituents from phenolic-rich extracts of Lagenaria siceraria and Sechium edule. Journal of Agricultural and Food Chemistry 61: 1008010090.

142. Susunaga GS, Siani AC, Pizzolatti MG, Yunes RA, Delle Monache F (2001) Triterpenes from the resin of Protium heptaphyllum. Fitoterapia 72: 709-711.

143. Takawale RV, Mali VR, Kapase CU, Bodhankar SL (2012) Effect of Lagenaria siceraria fruit powder on sodium oxalate induced urolithiasis in wistar rats. Journal of Ayuverda \& Integrative Medicine 3:75-79.

144. Tamil Selvi A, Dinesh MG, Satyan RS, Chandrasekaran B, Rose C (2011) Leaf and seed of Bixa Orellana L. exert anti-microbial activity against bacterial pathogens. Journal of Applied Pharmaceutical Science 1: 116-120.

145. Teugwa CM, Boudjeko T, Tchinda BT, Mejiato PC (2013) Antihyperglycaemic globulins from selected Cucurbitaceae seeds used as antidiabetic medicinal plants in Africa. BMC Complementary and Alternative Medicine 13:63-69.

146. Tian JS, Cui YL, Hu LM, Gao S, Chi W, Dong TJ, Liu LP (2010) Antidepressant-like effect of genipin in mice. Neuroscience Letters 479: 236-239.

147. Tsuruna K, Shimazaki H, Nakashima KI, Yamauchi M, Sugitami, S, Shimazawa $M$, linuma $M$, Hara $H$ (2012) Annatto prevents retinal degeneration induced by endoplasmatic reticulum stress in vitro and in vivo. Molecular and Nutrition Food Research 56: 713-724.

148. Tyagi N, Sharma GN, Hooda V (2012) Phytochemical and pharmacological profile of Lagenaria siceraria: An overview. International Journal Research of Pharmacy 3: 1-4.

149. Ueda S, Iwahashi Y (1991) Production of antitumor-promoting iridoid glycosides in Genipa americana and its cell cultures. Journal of Natural Products 54: 1677-1680.

150. Upaganlawar A, Balaraman R (2011) Caridoprotective effects of Lagenaria siceraria fruit juice on isoproterenol-induced myocardial infarction in wistar rats: $A$ biochemical and histoarchitecture study. Journal of Young Pharmacists 3: 297-303.

151. Venditti A, Serrilli AM, Bianco A (2013) Iridoids from Bellardia trixago (L.) All. Natural Product Research 27: 1413-1416.

152. Venugopalan A, Giridhar P, Ravishankar GA (2011) Food, ethnobotanical, and diversified application of Bixa orellana L.: Scope for its improvement through biotechnological mediation. Indian Journal of Fundamental and Applied Life Sciences 1: 9-31.

153. Venugopalan A, Gridhar $P$ (2012) Bacterial growth inhibition potential of annatto plant parts. Asian Pacific Journal of Tropical Biomedicine S1879-1882.

154. Vitor CE, Figueiredo CP, Hara DB, Bento AF, Mazzuco TL, Calixto JB (2009) Therapeutic action and underlying mechanisms of a combination of two pentacyclic triterpenes, $\alpha$ - and $\beta$-amyrin, in a mouse model colitis. British Jouirnal of Pharmacology 157 1034-1044.

155. Viuda-Martos M, Ciro-Gomez GL, Ruiz-Navajas Y. ZapataMontoya JE, Sendra E, Pérez-Álvarez JA, Fernández-Lopez $J(2012)$ In vitro antioxidant and antibacterial activities from annatto (Bixa orellana L.) leaves and seeds. Journal of Food Safety 32: 399-406.

156. Wang OS, Xiang Y, Cui YL, Lin nKM, Zhang XF (2012) Dietary blue pigments derived from genipin, attenuate inflammation by inhibition of LPS-induced iNOS and COX-2 expression via NF-kB inactivation. Plos0ne 7: e34122. 
157. Wang HX, Ng TB (2000) Lagenin, a novel ribosome-inactivating protein with ribonucleolytic activity from bottle gourd (Lagenaria sicerarai) seeds. Life Sciences 67: 2631-2638.

158. Wang J, Hou J, Zhang P, Li D, Zhang C, Liu J (2012) Geniposide reduces inflammatory responses of oxygen-glucose deprived rat microglial cells via inhibition of the TLR4 signaling pathway. Neurochemistry Research 37: 2235-2248.

159. Wang N, Zhu M, Tsao SW, Man K, Zhang Z, Feng Y (2012) Upregulation of TIMP-1 by genipin inhibits MMP-2 activities and suppresses the metastatic potential of human hepatocellular carcinoma. Plos0ne 7: e46318.

160. Yang X, Yao J, Luo Y, Han Y, Wang Z, Du, L (2013) P38 MAP kinase mediates apoptosis after genipin treatment in non-small-cell lung cancer $\mathrm{H1299}$ cells via a mitochondrial apoptotic cascade. Journal of Pharmacological Sciences 121: 272-281.

161. Yong YK, Arifal AK, Sukardi S, Roslida AH, Somchit MN, Zuraini A (2011) Bixa orellana leaves extracts inhibit bradykinin-induced inflammation through suppression of nitric oxide production. Medical and Principle Pratice 20: 142-146.

162. Yong YK, Zakaria ZA, Kadir AA, Somchit MN, Lian GEC, Ahmad $Z$ (2013a) Chemical constituents and antihistamine activity of Bixa orellana leaf extract. BMC Complementary and Alternative Medicine 13: 32-38.

163. Yong YK, Sulaiman NS, Hakim MN, Lian GEC, Zakaria ZA, Othman F, Ahmad Z (2013b) Suppression of serotonin-induced increased vascular permeability and leucocyte infiltration by Bixa orellana leaf extract. Biomed Research International Article 462145.

164. Zhang CY, Parton LE, Ye CP, Krauss S, Shen R, Lin CT, Porco Jr. JA, Lowell BB (2006) Genipin inhibits UCP2-mediated proton leak and acutely reverses obesity- andf high glucose-induced b-cell dysfunction in isolated pancreatic islet. Cell Metabolism 3: 417427.

165. Zhang G, He JL, Xie XY, Yu C. (2012) LPS-induced iNOS expression in $\mathbf{N 9}$ microglial cells is suppressed by geniposide via ERK, p38 and nuclear factor-kB signaling pathways. International Journal of Molecular Medicine 30: 561-568.

166. Zhang HY, Liu H, Yang M, Wei SE (2013) Antithrombotic activities of aqueous extract from Gardenia jasminoides. Pharmaceutical Biology 51: 221-225

167. Zhang Q, Su YQ, Zhang JF (2013) Seasonal variation I n antioxidant capacity and active compounds contents of Eucommia ulmoides Oliver leaf. Molecules 18: 1857-1868. 